\title{
Influence of Low Oxygen Concentration on Derepression of Nitrogenase in Klebsiella pneumoniae
}

\author{
By F. J. BERGERSEN, ${ }^{*}$ CHRISTINA KENNEDY ${ }^{2}$ AND SUSAN HILL ${ }^{2}$ \\ ${ }^{1}$ CSIRO, Division of Plant Industry, Canberra, A.C.T. 2601, A ustralia \\ ${ }^{2}$ A.R.C. Unit of Nitrogen Fixation, The University of Sussex, Brighton, Sussex BN1 9RQ, \\ U.K.
}

(Received 17 A ugust 1981)

\begin{abstract}
Effects of oxygen upon derepression of nitrogenase were studied in Klebsiella pneumoniae, using oxyleghaemoglobin to supply and monitor very low dissolved $\mathrm{O}_{2}$ concentrations in a steady-state system. Expression of the nifH gene was studied by using a nifH::lac fusion strain, which also carried the $\mathrm{Nif}^{+}$plasmid $\mathrm{pRD} 1$ so that the production of active nitrogenase could also be monitored. When compared with anaerobic treatments, very low concentrations of dissolved $\mathrm{O}_{2}$ inhibited derepression of both nifH::lac and pRD1 nif. Fifty percent inhibition of derepression occurred at $0.1 \mu \mathrm{M}-\mathrm{O}_{2}$. The apparent $K_{\mathrm{s}}$ of the dominant terminal oxidase was $0.08 \mu \mathrm{M}-\mathrm{O}_{2}$. These results suggest that there is a close relationship between the terminal respiratory system of these bacteria and the repression of nitrogenase by $\mathrm{O}_{2}$.
\end{abstract}

\section{INTRODUCTION}

Nitrogen fixation by Klebsiella spp. is primarily associated with the anaerobic mode of metabolism, although nitrogenase can be produced and is active when $\mathrm{O}_{2}$ supply limits growth (Klucas, 1972; Hill, 1976; Bergersen \& Turner, 1980). Repression by $\mathrm{O}_{2}$ of synthesis of nitrogenase (the products of the structural genes nifHDK) in $K$. pneumoniae was demonstrated by Eady et al. (1978), when derepressed cultures were bubbled with either $5 \%$ or $20 \%(\mathrm{v} / \mathrm{v}) \mathrm{O}_{2}$. Further work (Hill et al., 1981) showed that repression occurred with a dissolved oxygen tension of $0.25 \%\left(3 \mu \mathrm{M}-\mathrm{O}_{2}\right)$, but the lowest concentration needed to cause repression was not established.

Studies of $\mathrm{O}_{2}$ regulation of nif have been facilitated by the fusion of the $E$. coli lac $Z$ gene into the various transcriptional units of the nif gene cluster because expression from the various nif promoters results in an $\mathrm{O}_{2}$-stable product ( $\beta$-galactosidase) (Dixon et al., 1980). Such studies have revealed that a dissolved oxygen tension of $0.5 \%$ inhibited derepression of nifHDK but not of nifLA transcriptional units (Dixon et al., 1980) and that the nifL gene product is involved as a negative effector in the $\mathrm{O}_{2}$-regulatory mechanism specific to nitrogen fixation (Hill et al., 1981). Although strains carrying nif::lac fusions provide an easy way of measuring expression from nif promoters, such strains are $\mathrm{Nif}^{-}$; therefore we have used a strain carrying the $\mathrm{Nif}^{+}$plasmid $\mathrm{pRD} 1$, as well as a nifH::lac fusion.

In the present work we have used the technique of Bergersen \& Turner (1979), which employs the $\mathrm{O}_{2}$-binding protein leghaemoglobin to supply and monitor very low dissolved $\mathrm{O}_{2}$ concentration, in order to determine the concentrations of $\mathrm{O}_{2}$ that inhibit derepression of nifHDK and prevent nitrogenase activity in vivo.

\section{METHODS}

Media. Nutrient broth and nutrient agar were from Oxoid. NFDM medium was that of Cannon et al. (1974). Where indicated, it included $\left(\mathrm{NH}_{4}\right)_{2} \mathrm{SO}_{4}(10 \mathrm{~mm})$, histidine $\left(20 \mu \mathrm{g} \mathrm{ml}^{-1}\right)$, kanamycin $\left(\mathrm{Km}, 20 \mu \mathrm{g} \mathrm{ml}^{-1}\right)$, 
Table 1. Bacteria and plasmid

Genotype or phenotype

Klebsiella pneumoniae UNF767

Klebsiella pneumoniae CK260

Escherichia coli JC5466

Plasmid pRD1

\author{
hisD2 nifH2783 : : Mud(Aplac) lac4 recA56 \\ hisD2 nifH2260 hsdR1 rpsL4 \\ trp recA56 his rplE \\ $\mathrm{Km} \mathrm{Tc} \mathrm{Cb}$ Gnd His Nif ShiA Tra IncP
}

Reference or source

Hill et al. (1981)

Dixon et al. (1977)

Dixon et al. (1976)

Dixon et al. (1976)

streptomycin $\left(\mathrm{Sm}, 200 \mu \mathrm{g} \mathrm{m}^{-1}\right)$ and Noble agar $(1.5 \%, \mathrm{w} / \mathrm{v} ;$ Difco). Derepression medium contained potassium phosphate ( $95 \mathrm{~mm}, \mathrm{pH} 7 \cdot 2)$, sucrose $(29 \mathrm{~mm}), \mathrm{Na}_{2} \mathrm{MoO}_{4} \cdot 2 \mathrm{H}_{2} \mathrm{O}(0 \cdot 1 \mathrm{~mm})$.

Bacteria and plasmid. These are shown in Table 1. The plasmid pRD1, which carries the his-nif region of the $K$. pneumoniae chromosome, was transferred from E. coli strain JC5466 to UNF767 by conjugation (Dixon et al., 1976) on nutrient agar, followed by selection of transconjugants on NFDM plus $\mathrm{NH}_{4}^{+}$and kanamycin. Several transconjugant colonies were transferred to and maintained on NFDM plus $\mathrm{NH}_{4}^{+}$with minimal subculturing. In the course of the experiments, three different constructions were used, two prepared in Sussex and one in Canberra. In all respects they behaved similarly.

To ensure that subculturing and the experimental procedure did not produce an alteration or loss of pRD1 in the transconjugant strain, cultures were checked, after final sampling, for $\mathrm{His}^{+} \mathrm{Nif}^{+}$phenotype and for transfer of these characters to another $\mathrm{His}^{-} \mathrm{Nif}^{-}$mutant $K$. pneumoniae strain (CK260). Diluted culture samples were plated on $\mathrm{NFDM}+\mathrm{NH}_{4}^{+}$and, when grown, were replica plated either on to NFDM or on to lawns of $10^{7}$ cells of CK260 spread on the surfaces of $2 \mathrm{NFDM}+\mathrm{Sm}$ plates, one also containing $\mathrm{NH}_{4}^{+}$. Anaerobic growth was scored 3-4 d later. The former replica plating was performed after each experiment: for all data presented, the $\mathrm{His}^{+} \mathrm{Nif}^{+}$ phenotype of UNF767(pRD1) was maintained. The latter replica plating ensured that his and nif were transferable on pRD1 to CK260: only CK260(pRD1) transconjugants can grow on both plates, since UNF767(pRD1) is Sm ${ }^{s}$ and $\mathrm{CK} 260$ is $\mathrm{His}^{+}$and $\mathrm{Nif}^{-}$but $\mathrm{Sm}^{\mathrm{r}}$. Transferability was tested periodically during these experiments, and once indicated the need to use a freshly constructed UNF767(pRD1) culture.

Cultures. For derepression experiments, an overnight culture of UNF767(pRD1) was grown in NFDM $+\mathrm{NH}_{4}^{+}$ $(10 \mathrm{ml})$ at $30^{\circ} \mathrm{C}$ in air. This was used to inoculate $100 \mathrm{ml} \mathrm{NFDM}+\mathrm{NH}_{4}^{+}$in a Suba-Seal-capped Erlenmeyer flask $(150 \mathrm{ml})$, and the culture was grown for $20 \mathrm{~h}$ at $30^{\circ} \mathrm{C}$ under $\mathrm{N}_{2}$ with shaking at $150 \mathrm{rev}$. $\mathrm{min}^{-1}$. Two $40 \mathrm{ml}$ portions of the culture were transferred by syringe to $\mathrm{N}_{2}$-flushed, capped centrifuge tubes and the bacteria collected by centrifugation at $7500 \mathrm{~g}$ for $10 \mathrm{~min}$. The pellets were kept under the supernatants at ice temperature, under $\mathrm{N}_{2}$. Just before each experiment the supernatants were removed and the bacteria resuspended in 5 or $10 \mathrm{ml}$ degassed, ice-cold derepression medium. Portions $(1.0$ or $1.5 \mathrm{ml})$ were then transferred by syringe to the experimental vessels described below.

Derepression experiments. Anaerobic and $\mathrm{O}_{2}$ treatments were run in parallel. For anaerobic treatments the bacterial suspension was injected at zero time into $100 \mathrm{ml}$ Suba-Seal-capped Erlenmeyer flasks containing $16 \mathrm{ml}$ NFDM or derepression medium, degassed by evacuation and filled with 1 atm $\mathrm{N}_{2}$. The flasks were shaken reciprocally at 150 excursions $\mathrm{min}^{-1}$ at $30^{\circ} \mathrm{C}$ in a water bath. Samples $(2.0 \mathrm{ml})$ were withdrawn by argon-flushed syringes at intervals of approximately $1 \mathrm{~h}$.

For $\mathrm{O}_{2}$ treatments the apparatus of Bergersen \& Turner (1979) was used (Fig. 1). The reaction chamber (approx. vol. $16.4 \mathrm{ml}$ ) equipped with a magnetic stirrer and water jacket (needed to maintain the chamber contents at $30^{\circ} \mathrm{C}$ ) was flushed with argon and filled completely with degassed NFDM or derepression medium. At zero time, 1.0 or $1.5 \mathrm{ml}$ of bacterial suspension was injected into the chamber, and $\mathrm{O}_{2}$ was then immediately supplied to the bacteria. This was achieved by pumping through the chamber air-saturated $\left(240-267 \mu \mathrm{M}-\mathrm{O}_{2}\right.$ at $25^{\circ} \mathrm{C}$, according to the barometric pressure) derepression medium, containing about $100 \mu \mathrm{M}$-oxyleghaemoglobin (Appleby \& Bergersen, 1980), at a pre-determined rate appropriate to maintain the desired free $\mathrm{O}_{2}$ concentration in the effluent. The degree of oxygenation (Y) of the leghaemoglobin (Lb) and the equilibrium concentration of free dissolved $\mathrm{O}_{2}$ in the effluent (assumed to be equal to that in the chamber) were calculated as before (Bergersen \&

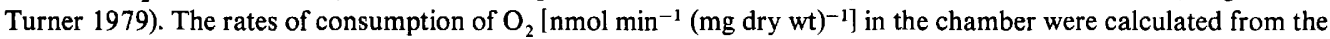
difference in concentrations of free $\mathrm{O}_{2}$ and of oxyleghaemoglobin between the medium supplied and the effluent from the chamber (Bergersen \& Turner 1979). Samples $(2.0 \mathrm{ml})$ of bacteria were withdrawn from the chamber at intervals of about $1 \mathrm{~h}$, using argon-flushed syringes connected through the port ( $\mathrm{i}_{2}$, Fig. 1) and closing tap (t). Removal of bacteria during sampling was taken into account when calculating rates of $\mathrm{O}_{2}$ consumption in the chamber. In most experiments steady levels of oxygenation of leghaemoglobin in the effluent were achieved within 15-20 min of zero time and were maintained for up to $6 \mathrm{~h}$ by adjusting flow rates slightly as required, especially following sampling. Data from a typical experiment are given in Table 2.

Treatment of samples. Immediately following the collection of each sample, $0.5 \mathrm{ml}$ was used for a nitrogenase assay. The balance was quickly chilled to $0-0.5^{\circ} \mathrm{C}$ by delivery into a prechilled glass tube immersed in ice. 


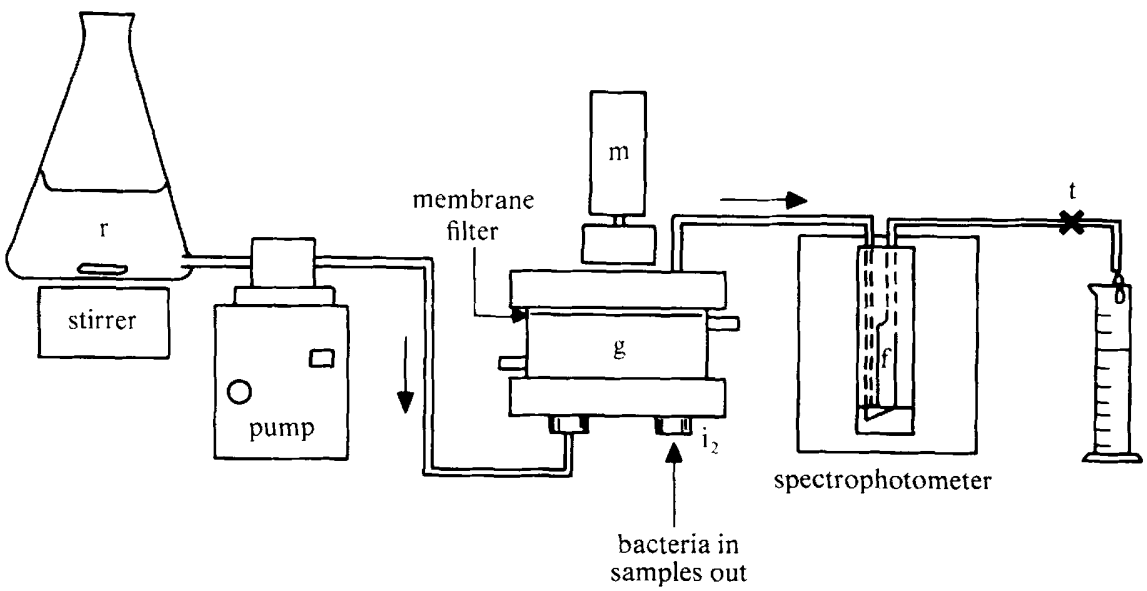

Fig. 1. A schematic diagram of the apparatus for steady $\mathrm{O}_{2}$ supply: $\mathrm{r}$, reservoir of derepression medium containing leghaemoglobin and stirred in air at $25^{\circ} \mathrm{C}$; g, reaction chamber with water jacket (for design details see Bergersen \& Turner, 1979) and magnetic stirrer, $m$; f, spectrophotometer flow cell; $t$, a stopcock; $i_{2}$, an injection port.

\section{Table 2. Results of a typical experiment in the reaction chamber}

Initially $8.79 \mathrm{mg}$ (dry wt) of UNF767(pRD1) were present. The inflowing medium contained $101.5 \mu \mathrm{M}$-oxyleghaemoglobin and $245 \mu \mathrm{M}$ free dissolved $\mathrm{O}_{2}$.

\begin{tabular}{|c|c|c|c|c|c|}
\hline \multirow[b]{2}{*}{$\begin{array}{l}\text { Elapsed } \\
\text { time } \\
\text { (h) }\end{array}$} & \multicolumn{2}{|c|}{ Effluent medium } & \multirow[b]{2}{*}{$\begin{array}{l}\text { Bacteria in } \\
\text { chamber } \\
\text { (mg dry wt) }\end{array}$} & \multirow[b]{2}{*}{$\begin{array}{c}\text { Medium } \\
\text { flow } \\
(\mathrm{ml} \mathrm{min}-1)\end{array}$} & \multirow[b]{2}{*}{$\begin{array}{l}\mathrm{O}_{2} \text { consumption } \\
{\left[\mathrm{nmol} \mathrm{O}_{2} \mathrm{~min}^{-1}\right.} \\
\left.(\mathrm{mg} \text { dry } \mathrm{wt})^{-1}\right]\end{array}$} \\
\hline & $\begin{array}{c}\text { Lb oxygenation } \\
(\mathrm{Y})\end{array}$ & $\begin{array}{c}\text { Free } \mathrm{O}_{2} \\
(\mu \mathrm{M})\end{array}$ & & & \\
\hline 0.33 & 0.686 & 0.081 & \multirow[t]{5}{*}{8.79} & 0.73 & $23 \cdot 1$ \\
\hline 0.43 & 0.638 & 0.066 & & 0.81 & $26 \cdot 0$ \\
\hline 0.58 & 0.563 & 0.058 & & 0.93 & $30 \cdot 6$ \\
\hline 0.67 & 0.615 & 0.060 & & 0.97 & $31 \cdot 3$ \\
\hline 0.83 & 0.593 & 0.055 & & 0.96 & $31 \cdot 3$ \\
\hline 1.02 & 0.563 & 0.048 & \multirow{2}{*}{7.98} & 0.96 & $34 \cdot 8$ \\
\hline 1.08 & 0.569 & 0.049 & & 0.97 & $35 \cdot 1$ \\
\hline $1 \cdot 33$ & 0.581 & 0.052 & & 0.99 & 35.7 \\
\hline 1.58 & 0.569 & 0.049 & \multirow{2}{*}{$\downarrow$} & 0.99 & $35 \cdot 8$ \\
\hline 1.83 & 0.569 & 0.049 & & 1.04 & $37 \cdot 6$ \\
\hline 2.08 & 0.581 & 0.052 & \multirow[t]{4}{*}{$7 \cdot 46$} & 0.98 & $33 \cdot 8$ \\
\hline $2 \cdot 33$ & 0.600 & 0.056 & & 0.98 & 37.9 \\
\hline 2.67 & 0.638 & 0.066 & & 1.00 & $37 \cdot 4$ \\
\hline 2.92 & 0.619 & 0.061 & & 0.93 & 35.4 \\
\hline 3.08 & 0.594 & 0.055 & 7.05 & 0.96 & 39.0 \\
\hline $3 \cdot 33$ & 0.594 & 0.055 & 1 & 0.91 & $36 \cdot 9$ \\
\hline 3.67 & 0.594 & 0.055 & \multirow{2}{*}{$\downarrow$} & 0.93 & $37 \cdot 8$ \\
\hline $3 \cdot 83$ & 0.574 & 0.050 & & 0.93 & 38.0 \\
\hline 4.08 & 0.588 & 0.053 & 6.73 & 0.93 & 39.6 \\
\hline $4 \cdot 33$ & 0.615 & 0.060 & & 0.93 & $39 \cdot 3$ \\
\hline 4.58 & 0.625 & 0.062 & \multirow{2}{*}{$\downarrow$} & \multirow{2}{*}{$\begin{array}{l}0.93 \\
0.94\end{array}$} & $39 \cdot 1$ \\
\hline \multirow[t]{2}{*}{5.00} & 0.631 & 0.064 & & & 39.5 \\
\hline & \multicolumn{2}{|c|}{$\begin{array}{c}\overrightarrow{\mathrm{x}}=0.057 \\
\text { (s.D. } 0.007)\end{array}$} & & & $\begin{array}{l}\bar{x}=34.6 \\
(\text { s.D. 5.19) }\end{array}$ \\
\hline
\end{tabular}

Samples containing leghaemoglobin were centrifuged at $0^{\circ} \mathrm{C}$ and the bacteria resuspended in the same volume $(1.5 \mathrm{ml})$ of cold derepression medium and kept on ice. At the end of the experiment, the samples were assayed for $\beta$-galactosidase activity $(0.5 \mathrm{ml})$ and the balance was used to determine absorbance at $600 \mathrm{~nm}$ and $700 \mathrm{~nm}$.

Assays. Nitrogenase activity in samples from derepression experiments was assayed in capped small bottles $(4.85 \mathrm{ml})$, filled with $5 \% \mathrm{C}_{2} \mathrm{H}_{2}$ in argon. The samples of bacteria $(0.5 \mathrm{ml})$ were injected and the bottle was shaken 
for $30 \mathrm{~min}$ at $30^{\circ} \mathrm{C}$. The reactions were stopped by injecting $0.2 \mathrm{ml} 10 \%(\mathrm{w} / \mathrm{v})$ trichloroacetic acid. Production of $\mathrm{C}_{2} \mathrm{H}_{4}$ from $\mathrm{C}_{2} \mathrm{H}_{2}$ was measured by gas chromatography (Turner \& Gibson 1980).

$\beta$-galactosidase activity was measured, using $0.5 \mathrm{ml}$ portions of samples, by the method described by Miller (1972).

Leghaemoglobin concentrations were measured using the pyridine haemochrome method (Appleby \& Bergersen, 1980).

Dry weights of bacteria present in samples were estimated using $A_{700}$ values and a standard curve prepared previously for K. pneumoniae (Bergersen \& Turner, 1980).

\section{RESULTS AND DISCUSSION}

\section{Nutritional requirements during derepression of nifH ::lac ( $p R D 1)$}

Preliminary experiments utilized NFDM as the derepression medium (Dixon et al., 1980); however, when high rates of $\mathrm{O}_{2}$ supply were used in the chamber, the bacteria agglutinated into a brownish gel which adhered to the stirrer. This effect was minimized when sucrose was substituted for glucose and the $\mathrm{MgSO}_{4}, \mathrm{Na}_{2} \mathrm{MoO}_{4}$ and $\mathrm{FeSO}_{4}$, which were supplied in a stock solution, were omitted. However $\mathrm{MoO}_{4}^{2-}$ promotes derepression of $\beta$-galactosidase in another strain of $K$. pneumoniae containing a plasmid carrying nifH::lac (Dixon et al., 1980) and this was found to be the case with UNF767(pRD1) also (Fig. 2). Sucrose concentration also affected the rate of derepression (Fig. $2 a$ ). These results led us to use derepression medium containing $1 \%$ sucrose, $95 \mathrm{~mm}$-potassium phosphate (as in NFDM) and $0.1 \mathrm{mM}-\mathrm{Na}_{2} \mathrm{MoO}_{4}$; in this medium derepression under anaerobic conditions was similar to that in NFDM, but agglutination of bacteria in the chamber was insignificant.

\section{Time course of derepression of nif $\mathrm{H}:$ : lac with $\mathrm{O}_{2}$}

Low concentrations of $\mathrm{O}_{2}(0.02-0.06 \mu \mathrm{M})$ invariably stimulated the early stages of derepression, compared with anaerobic treatments, but later on, organisms from anaerobic treatments always had higher activity; data for a typical experiment are shown in Fig. 3. With increased concentrations of $\mathrm{O}_{2}$, rates of derepression declined, reaching very low values at $2.6 \mu \mathrm{M}-\mathrm{O}_{2}$ (Fig. 3). Results of nitrogenase assays were completely parallel to results of $\beta$-galactosidase assays (Fig. 4) but, as found previously (Dixon et al., 1980), the appearance of $\beta$-galactosidase activity preceded the appearance of nitrogenase activity by about $1 \mathrm{~h}$ (Figs. $2,4)$.

\section{Consumption of $\mathrm{O}_{2}$ and determination of apparent $\mathrm{K}_{\mathrm{s}}$}

Steady-state rates of $\mathrm{O}_{2}$ consumption were calculated as shown in Table 2. Data from experiments are illustrated in Table 3 and Fig. 5. The individual values (Table 3) were obtained with acceptable precision, being based on up to 35 estimations during each steady state. The estimate of the apparent $K_{\mathrm{s}}$ for $\mathrm{O}_{2}$ uptake of $0.08 \mu \mathrm{M}$ (Fig. 5) is very similar to that measured for another strain, $K$. pneumoniae strain $50231(0.1 \mu \mathrm{M}$; Bergersen \& Turner, 1980). The experimental design in the present investigation did not permit the study of induction of this terminal oxidase of moderately high affinity. However, the data for strain 50231 (Bergersen \& Turner, 1980) suggest that this principal terminal oxidase is constitutive, since similar values for apparent $K_{\mathrm{s}}$ were obtained from chemostat populations grown either anaerobically or at low concentrations of dissolved $\mathrm{O}_{2}$.

\section{$\mathrm{O}_{2}$ concentration and derepression}

Hill et al. (1981) reported that derepression of $\beta$-galactosidase was inhibited by a dissolved oxygen concentration of $0.5 \%\left(6 \mu \mathrm{M}-\mathrm{O}_{2}\right)$ in strain UNF767 carrying pRD1. Our results show that even at an $\mathrm{O}_{2}$ concentration of $2.6 \mu \mathrm{M}$, very little derepression occurs in this strain (Fig. 4). This concentration of $2.6 \mu \mathrm{M}-\mathrm{O}_{2}$ is much lower than the dissolved oxygen tension of $10 \mathrm{mmHg}\left(16 \mu \mathrm{M}-\mathrm{O}_{2}\right)$ which allowed some nitrogenase synthesis in another species of Klebsiella (Klucas, 1972). This suggests that there may be differences in the apparent 


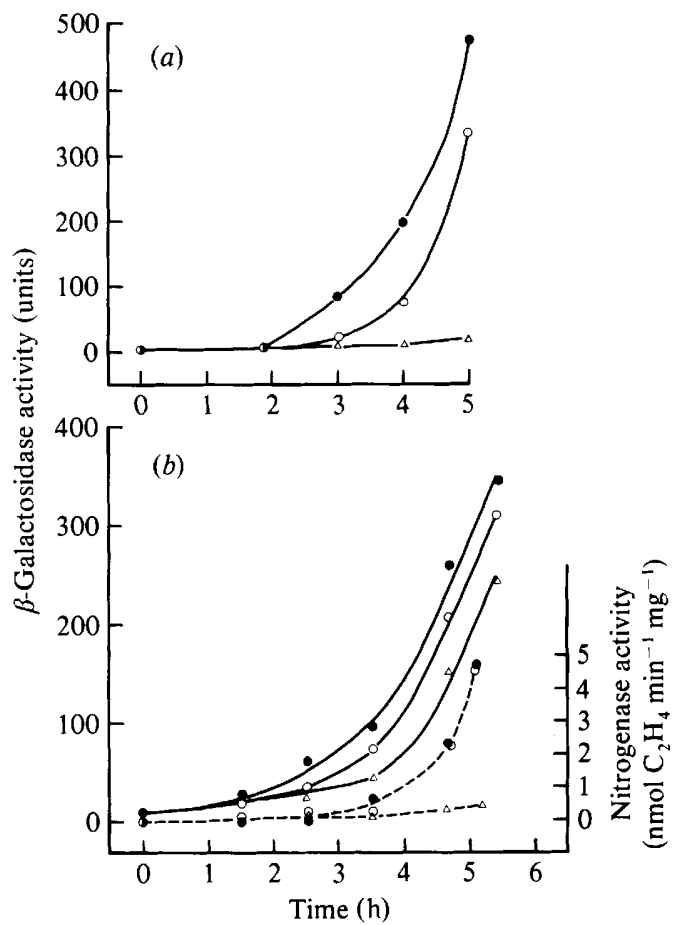

Fig. 2. Effects of composition of medium during nifH::lac derepression (data for anaerobic experiments). (a) NFDM, but with $1 \%$ sucrose instead of glucose (O); NFDM with $0.5 \%$ sucrose instead of glucose $(\mathrm{O}) ; 1 \%$ sucrose but with $\mathrm{Mo}, \mathrm{Fe}$ and $\mathrm{Mg}$ at $1 / 10$ concentration $(\triangle$; see text for composition). (b) $1 \%$ sucrose in 95 mm-potassium phosphate ( $\mathrm{pH} \mathrm{7.2)} \mathrm{with} \mathrm{Fe}, \mathrm{Mo}$ and $\mathrm{Mg}$ as in NFDM (O), with $0.1 \mathrm{mMNa}_{2} \mathrm{MoO}_{4}$ only (O), or with $0.8 \mathrm{~mm}-\mathrm{MgSO}_{4}$ only $(\triangle)$. The continuous lines show $\beta$-galactosidase activity; the dashed lines show nitrogenase activity.

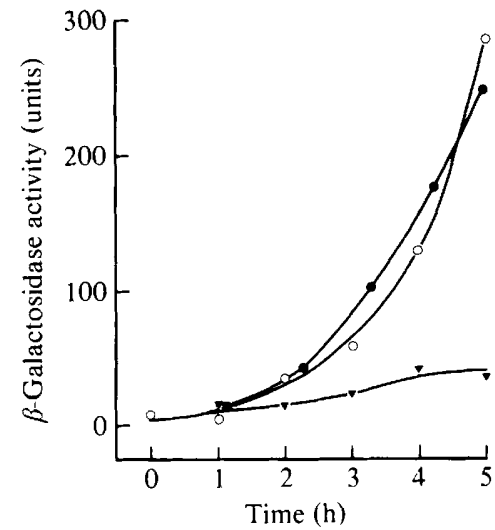

Fig. 3

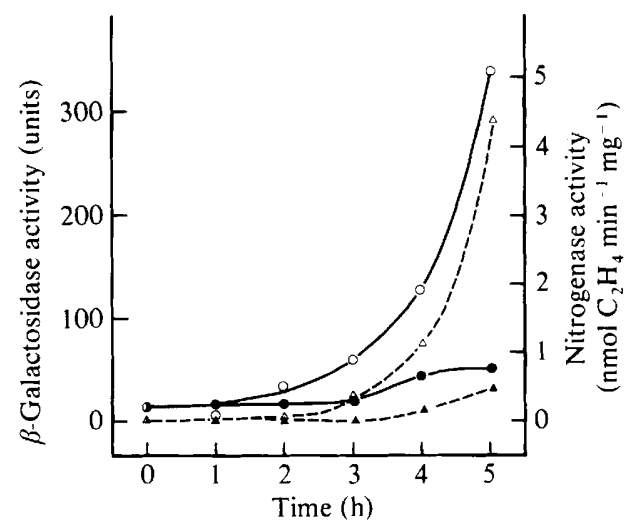

Fig. 4

Fig. 3. Typical time course of derepression of nif $\mathrm{H}:$ : lac. Anaerobic treatments were shaken under $\mathrm{N}_{2}$ (O). Oxygen treatments: $0.027 \mu \mathrm{M}-\mathrm{O}_{2}(\bigcirc) ; 2.6 \mu \mathrm{M}-\mathrm{O}_{2}(\nabla)$.

Fig. 4. Correspondence between derepression of nifH::lac $(\beta$-galactosidase activity: $\bigcirc, O)$ and pRDI nif (nitrogenase activity: $\Delta, \Delta$ ). Anaerobic treatment $(\mathrm{O}, \Delta)$ and $2.6 \mu \mathrm{M}-\mathrm{O}_{2}(\mathbf{O}, \Delta)$.

sensitivities of the repression mechanism of nitrogenase synthesis in various Klebsiella species. Almost certainly there will be a gradient of $\mathrm{O}_{2}$ concentration between that in the medium, the value measured, and that at the site of nitrogenase synthesis within the cell. Thus the different 


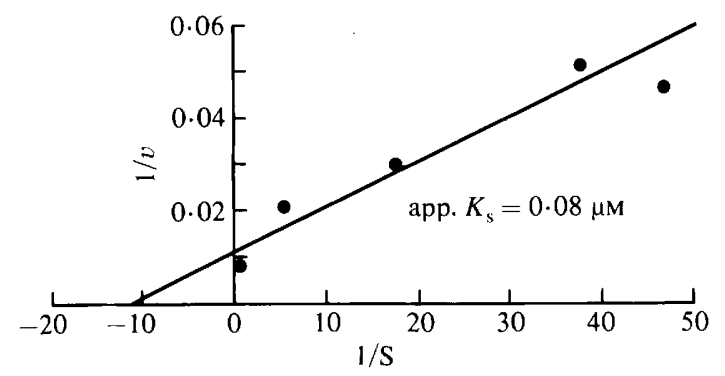

Fig. 5. Estimation of apparent $K_{\mathrm{s}}$ of the principal terminal oxidase of UNF767(pRD1) (data from Table 3).

Table 3. Respiration of UNF767( $p R D 1)$ during steady states

The values in parentheses are standard deviations for means of 22-35 estimations in each experiment.

\begin{tabular}{|c|c|c|}
\hline $\begin{array}{l}\text { Expt. } \\
\text { no. }\end{array}$ & $\begin{array}{l}{\left[\mathrm{O}_{2 \text { free }}\right]} \\
(\mu \mathrm{M})\end{array}$ & $\begin{array}{c}\mathrm{O}_{2} \text { consumption } \\
\left\{\text { nmol } \mathrm{O}_{2} \min ^{-1}(\mathrm{mg} \text { dry wt })^{-1}\right\}\end{array}$ \\
\hline 3 & $0.0215(0.0042)$ & $21.5 \quad(3.0)$ \\
\hline 1 & $0.027 \quad(0.004)$ & $18 \cdot 7 \quad(3 \cdot 3)$ \\
\hline 4 & $0.057 \quad(0.007)$ & $34.6 \quad(5.2)$ \\
\hline 5 & $0.193 \quad(0.072)$ & $42.8 \quad(1.7)$ \\
\hline 2 & $2.59 \quad(0.37)$ & $106 \cdot 6(11 \cdot 2)$ \\
\hline
\end{tabular}

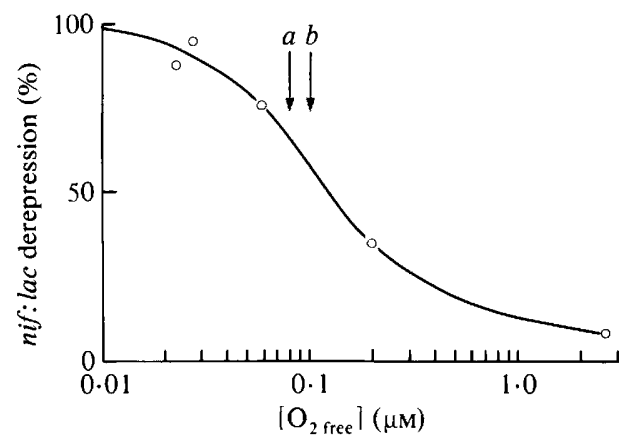

Fig. 6. Relationship between concentration of $\mathrm{O}_{2}$ and derepression of nifH::lac in UNF767(pRD1). Percentage derepression was calculated from each experiment as: $100 \times\left[\beta\right.$-galactosidase $\left.\left(\mathrm{O}_{2}\right)\right] /$ [ $\beta$-galactosidase (anaerobic)]. The apparent $K_{\mathrm{s}}$ of the terminal oxidase of $K$. pneumoniae is indicated by arrows: (a) this work, (b) Bergersen \& Turner (1980).

apparent sensitivities to repression may reflect the magnitude of the $\mathrm{O}_{2}$ gradient in the different experimental systems used.

Figure 6 shows the influence of dissolved $\mathrm{O}_{2}$ concentration on $\beta$-galactosidase activities during the various experiments, expressed as a percentage activity of parallel anaerobic treatments, all measured $5 \mathrm{~h}$ after removal of $\mathrm{NH}_{4}^{+}$and commencement of $\mathrm{O}_{2}$ treatment. It is clear that $50 \%$ inhibition of derepression was obtained at an $\mathrm{O}_{2}$ concentration close to the apparent $K_{\mathrm{s}}$ of the constitutive principal terminal oxidase. At this $\mathrm{O}_{2}$ concentration sufficient $\mathrm{O}_{2}$ may penetrate the cell to interfere with nif gene expression. Alternatively, due to the fairly high affinity of the principal constitutive terminal oxidase for $\mathrm{O}_{2}$, the enzyme could act as a sensitive monitor for $\mathrm{O}_{2}$ concentration. Inhibition of expression from the nifH promoter, a process probably mediated through the nifL gene product (Hill et al., 1981), could thus be triggered by the oxidized form of the terminal oxidase or some other oxidized component of the electron transport pathway. 


\section{REFERENCES}

Appleby, C. A \& Bergersen, F. J. (1980). Preparation and experimental use of leghaemoglobin. In Methods for Evaluating Biological Nitrogen Fixation, pp. 315-335. Edited by F. J. Bergersen. Chichester: Wiley.

Bergersen, F. J. \& Turner, G. L. (1979). Systems utilizing oxygenated leghaemoglobin and myoglobin as sources of free dissolved $\mathrm{O}_{2}$ at low concentrations for experiments with bacteria. Analytical Biochemistry 96, 165-174.

Bergersen, F. J. \& Turner, G. L. (1980). Properties of terminal oxidase systems of bacteroids from root nodules of soybean and cowpea and of $\mathrm{N}_{2}$-fixing bacteria grown in continuous culture. Journal of General Microbiology 118, 235-252.

Cannon, F. C., Dixon, R. A., Postgate, J. R. \& Primrose, S. B. (1974). Chromosomal integration of Klebsiella nitrogen fixation genes in Escherichia coli. Journal of General Microbiology 80, 227-239.

Dixon, R. A., Cannon, F. \& Kondorosi, A. (1976). Construction of a $\mathrm{P}$ plasmid carrying nitrogen fixation genes from Klebsiella pneumoniae. Nature, London 260, 268-271.

Dixon, R., Kennedy, C., Kondorosi, A., Krishinapillai, V. \& Merrick, M. (1977). Complementation analysis of Klebsiella mutants defective in nitrogen fixation. Molecular and General Genetics 157, 189-198.

DiXon, R., EADY, R. R., EsPIN, G., HILl, S.,
IAcCarino, M., KahN, D. \& Merrick, M. (1980). Analysis of regulation of Klebsiella pneumoniae nitrogen fixation (nif) gene cluster with gene fusions. Nature, London 286, 128-132.

Eady, R. R., Issack, R., Kennedy, C., Postgate, J. R. \& RATClifFe, H. D. (1978). Nitrogenase synthesis in Klebsiella pneumoniae: comparison of ammonium and oxygen regulation. Journal of General Microbiology 104, 277-285.

HILL, S. (1976). Influence of atmospheric oxygen concentration on acetylene reduction and efficiency of nitrogen fixation in intact Klebsiella pneumoniae. Journal of General Microbiology 93, 335-345.

Hill, S., Kennedy, C., Kavanagh, E., Goldberg, R. B. \& HANAU, R. (1981). Nitrogen fixation gene (nifL) involved in oxygen regulation of nitrogenase synthesis in Klebsiella pneumoniae. Nature, London 290, 424-426.

KLUCAS, R. V. (1972). Nitrogen fixation by Klebsiella grown in the presence of oxygen. Canadian Journal of Microbiology 18, 1845-1850.

Miller, J. H. (1972). Assay of $\beta$-galactosidase. In Experiments in Molecular Genetics, pp. 253-355. New York: Cold Spring Harbor Laboratory.

Turner, G. L. \& Gibson, A. H. (1980). Measurement of nitrogen fixation by indirect means. In Methods for Evaluating Biological Nitrogen Fixation, pp. 111-138. Edited by F. J. Bergersen. Chichester: Wiley. 